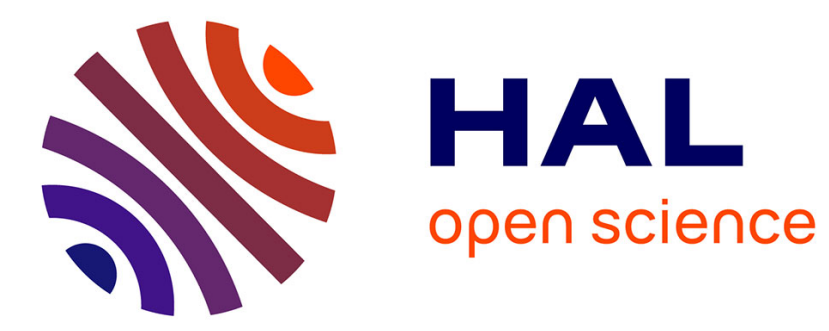

\title{
Pseudochrysogorgia bellona n. gen., n. sp.: a new genus and species of chrysogorgiid octocoral (Coelenterata, Anthozoa) from the Coral Sea
}

\author{
Eric Pante, Scott France
}

\section{- To cite this version:}

Eric Pante, Scott France. Pseudochrysogorgia bellona n. gen., n. sp.: a new genus and species of chrysogorgiid octocoral (Coelenterata, Anthozoa) from the Coral Sea. Zoosystema, 2010, pp.595-612. 10.5252/z2010n4a4 . hal-01097681

\section{HAL Id: hal-01097681 \\ https://hal.science/hal-01097681}

Submitted on 20 Dec 2014

HAL is a multi-disciplinary open access archive for the deposit and dissemination of scientific research documents, whether they are published or not. The documents may come from teaching and research institutions in France or abroad, or from public or private research centers.
L'archive ouverte pluridisciplinaire HAL, est destinée au dépôt et à la diffusion de documents scientifiques de niveau recherche, publiés ou non, émanant des établissements d'enseignement et de recherche français ou étrangers, des laboratoires publics ou privés. 


\title{
Pseudochrysogorgia bellona n. gen., n. sp.: a new genus and species of chrysogorgiid octocoral (Coelenterata, Anthozoa) from the Coral Sea
}

\author{
Eric PANTE \\ Scott C. FRANCE \\ Department of Biology, University of Louisiana at Lafayette, \\ P.O. Box 42451, Lafayette LA 70504 (USA) \\ pante@louisiana.edu \\ france@louisiana.edu
}

\author{
KEY WORDS \\ Cnidaria, \\ Coelenterata, \\ Anthozoa, \\ Octocorallia, \\ Calcaxonia, \\ Chrysogorgiidae, \\ New Caledonia, \\ New Zealand, \\ monopodial stem, \\ new genus, \\ new species.
}

MOTS CLÉS Cnidaria, Coelenterata, Anthozoa,

Octocorallia,

Calcaxonia, Chrysogorgiidae,

Nouvelle-Calédonie,

Nouvelle-Zélande, tronc monopodial, nouveau genre, nouvelle espèce.
Pante E. \& France S. C. 2010. - Pseudochrysogorgia bellona n. gen., n. sp.: a new genus and species of chrysogorgiid octocoral (Coelenterata, Anthozoa) from the Coral Sea. Zoosystema 32 (4): 595-612.

\begin{abstract}
A new genus and species of deep-sea Chrysogorgiidae Verrill, 1883, Pseudochrysogorgia bellona n. gen. n. sp., is described from colonies collected in the Coral Sea, West of New Caledonia (southwestern Pacific Ocean). These specimens bear resemblance to the genera Chrysogorgia Duchassaing \& Michelotti, 1864 (dichotomously-subdivided branches arising from the main stem in a spiraling fashion; polyps characterized by ornamented sclerites) and Metallogorgia Versluys, 1902 (colony monopodial, hexagonal branching pattern). Additional material collected North of New Zealand (Otara Seamount) is used to complete the description of this new genus. Its taxonomic rank is discussed in light of morphology- and DNA-based phylogenetic inference and analysis of genetic distances among deep-sea chrysogorgiid genera.
\end{abstract}

\section{RÉSUMÉ}

Pseudochrysogorgia bellona $n$. gen, $n$. sp.: un genre nouveau et une nouvelle espèce d'octocorail Chrysogorgiidae (Coelenterata, Anthozoa) de la Mer de Corail.

Un nouveau genre et une nouvelle espèce de Chrysogorgiidae Verrill, 1883 de grande profondeur, Pseudochrysogorgia bellona n. gen., n. sp., sont décrits à partir de colonies échantillonnées en Mer de Corail, à l'ouest de la Nouvelle-Calédonie (Pacifique sud-ouest). Ces spécimens ressemblent aux genres Chrysogorgia Duchassaing \& Michelotti, 1864 (branches subdivisées de façon dichotomique et émergeant du tronc principal en spirale; polypes caractérisés par des sclérites ornementés) et Metallogorgia Versluys, 1902 (colonie monopodiale, ramification des branches selon un motif hexagonal). Du matériel supplémentaire, prélevé au nord de la Nouvelle-Zélande (Otara Seamount), est utilisé pour compléter la description de ce nouveau genre. Son rang taxonomique est discuté à partir d'une analyse phylogénétique basée sur des données morphologiques et moléculaires, ainsi qu'à partir d'une analyse des distances génétiques entre les genres de coraux chrysogorgiidés. 


\section{INTRODUCTION}

The family Chrysogorgiidae Verrill, 1883 is distributed worldwide within a wide depth-range (10 to $3375 \mathrm{~m}$; Cairns 2001). Most species (> 75\%) seem restricted to deep water, inhabiting soft and hard bottoms. Although there is no published quantification of their abundance, chrysogorgiids are considered relatively common by deep-sea biologists, and often co-occur with isidids and primnoids. Recent expeditions using remotely-operated vehicles (ROVs) (MOUNTAINSIN-THE-SEA, 2003-2004 and DEEP ATLANTIC STEPPING STONES, 2005; northwestern Atlantic) revealed chrysogorgiids as among the tallest and most majestic octocoral colonies inhabiting the Corner and New England Seamounts (Watling 2007).

While a few genera are relatively diverse, most comprise few species, and are known from only a few specimens. For instance, the genus Chrysogorgia Duchassaing \& Michelotti, 1864 (> 60 nominal species) is one of the most speciose of the 274 alcyonacean genera, yet 12 of the 13 chrysogorgiid genera consist of fewer than 10 nominal species. This "taxonomic asymmetry" could be due to the evolutionary history of the family. However, the relatively limited number of taxonomists working on the Chrysogorgiidae, and the difficulty of obtaining specimens (most chrysogorgiids are found in the deep-sea), could significantly bias our view of the diversity within this group.

The Muséum national d'Histoire naturelle, Paris, hosts a large collection of octocorals from cruises that were aimed at describing biodiversity in the Indo-Pacific (Tropical Deep-Sea Benthos program; formerly MUSORSTOM). The present contribution is part of a larger research effort aiming at characterizing the chrysogorgiid fauna from these collections. Herein, we describe Pseudochrysogorgia bellona n. gen. n. sp., a new genus and species within the family Chrysogorgiidae, provide a revised dichotomous key to the common deep-sea genera of chrysogorgiid corals, and present for the first time SEM photographs for the polyps and sclerites of Metallogorgia Versluys, 1902, phylogenetically the closest relative of Pseudochrysogorgia n. gen. Comparing polyps and sclerites of Metallogorgia and Pseudochrysogorgia n. gen. will help to distinguish these genera unequivocally.

\section{MATERIAL AND METHODS}

\author{
ABBREVIATIONS \\ $\mathrm{CP} \quad$ chalut à perche (beam trawl); \\ EBISCO Exploration de la Biodiversité et Isolement \\ en Mer de Corail; \\ MNHN Muséum national d'Histoire naturelle, Paris; \\ NIWA National Institute of Water \& Atmospheric \\ Research, Wellington; \\ SEM scanning-electron microscopy; \\ stn station; \\ USNM United States National Museum, Washington \\ DC.
}

\section{MATERIAL}

This study is based on the examination of two colonies collected in October 2005 during the cruise EBISCO (Tropical Deep-sea Benthos program; French vessel NO Alis), organized by the MNHN. Both colonies were trawled at the same station on the Bellona Plateau, West of New Caledonia (southwestern Pacific Ocean). Colonies were preserved in $80 \%$ ethanol and are deposited at the MNHN. Additional material was provided by the NIWA Invertebrate Collection. These colonies were collected in November 2004 on Otara Seamount, on the southern end of the Kermadec Ridge, North of New Zealand. They were preserved in ethanol, and are held at the NIWA. We were not able to examine whole specimens from the NIWA collection, and therefore we were not able to assess all morphological characters. However, we could establish that polyp and sclerite morphology, and sclerite orientation were consistent with the MNHN material. In addition, DNA sequences from the mitochondrial gene $m s h 1$ were identical. There is therefore little doubt that these specimens belong to the same taxon as the MNHN material. NIWA 16273 was preserved with an intact holdfast, which is absent from all other colonies available. This specimen was therefore included in the type series. Comparative material of Chrysogorgia and Metallogorgia was made available by the MNHN and the NIWA. These specimens are C. admete Bayer \& Stefani, 1988 (holotype; MNHN-IC.0000-0274), M. melanotrichos (Wright \& Studer, 1889) (NIWA 43024) and M. macrospina Kükenthal, 1919 (MNHN-IK-2008-1042). Polyps from MAN806-1, a specimen of $M$. melanotrichos collected on Manning Seamount (NW Atlantic) in 
TABLE 1. - List of specimens examined in this study. Specimens with three associated GenBank accession numbers were used in the DNA-based phylogenetic analysis. Where there is only one GenBank accession number, it corresponds to $m s h 1$. The isolate corresponds to the genetic subsample maintained in the SCF Lab at UL Lafayette. Voucher in italics: type material.

\begin{tabular}{|c|c|c|c|c|c|c|c|}
\hline Species & Isolate & Voucher & Sampling & Depth (m) & Lat. & Long. & $\begin{array}{l}\text { GenBank (msh1, } \\
\text { cox1, 18S) }\end{array}$ \\
\hline $\begin{array}{l}\text { Calyptrophora wyvillei } \\
\text { Wright, } 1885\end{array}$ & LAD36 & $\begin{array}{l}\text { USNM } \\
98815\end{array}$ & 20.IX.1996 & 1225 & 20.470 & -157.149 & $\begin{array}{l}\text { EU293801, } \\
\text { GQ868317, } \\
\text { HM590863 }\end{array}$ \\
\hline $\begin{array}{l}\text { Narella dichotoma } \\
\text { Versluys, } 1906\end{array}$ & LAD12 & $\begin{array}{l}\text { USNM } \\
98831\end{array}$ & 20.IX.1996 & 1451 & 20.470 & -157.149 & $\begin{array}{l}\text { EU293800, } \\
\text { GQ868316, } \\
\text { HM590862 }\end{array}$ \\
\hline $\begin{array}{l}\text { Chrysogorgia admete } \\
\text { Bayer \& Stefani, } 1988\end{array}$ & 340617 & $\begin{array}{l}\text { MNHN-IC. } \\
0000-0274\end{array}$ & 13.IV.1978 & 390 & -22.817 & 167.200 & \\
\hline $\begin{array}{l}\text { Chrysogorgia chryseis } \\
\text { Bayer \& Stefani, } 1988\end{array}$ & CR106-2 & & 18.VIII.1993 & 1010 & 18.777 & -158.247 & $\begin{array}{l}\text { DQ297421, } \\
\text { GQ868308, } \\
\text { AF052913 }\end{array}$ \\
\hline $\begin{array}{l}\text { Iridogorgia } \\
\text { magnispiralis Watling, } \\
2007\end{array}$ & KEL403-2 & YPM 38580 & 19.V.2004 & 2311 & 38.779 & -63.963 & $\begin{array}{l}\text { DQ860108, } \\
\text { DQ860111, } \\
\text { FJ526216 }\end{array}$ \\
\hline $\begin{array}{l}\text { Metallogorgia macro- } \\
\text { spina Kükenthal, } 1919\end{array}$ & HAL2033-2 & $\begin{array}{l}\text { MNHN-IK- } \\
2008-1042\end{array}$ & 12.XI.1996 & $699-1280$ & -25.317 & 168.967 & \\
\hline $\begin{array}{l}\text { Metallogorgia melano- } \\
\text { trichos (Wright \& } \\
\text { Studer, 1889) }\end{array}$ & LYM210-1 & & 14.VIII.2005 & 2143 & 35.194 & -47.677 & $\begin{array}{l}\text { GQ180151, } \\
\text { FJ268630, } \\
\text { FJ526214 }\end{array}$ \\
\hline $\begin{array}{l}\text { Metallogorgia } \\
\text { melanotrichos }\end{array}$ & MAN806-1 & & 16.V.2004 & 1485 & 38.144 & -61.941 & \\
\hline $\begin{array}{l}\text { Metallogorgia } \\
\text { melanotrichos }\end{array}$ & NIWA 43024 & NIWA 43024 & 11.II.1996 & $1292-1496$ & -35.366 & 178.553 & GQ180146 \\
\hline $\begin{array}{l}\text { Pseudochrysogorgia } \\
\text { bellona n. gen., n. sp. }\end{array}$ & EBI 2557-1 & $\begin{array}{l}\text { MNHN-IC. } \\
2008-006\end{array}$ & 12.X.2005 & $800-923$ & -21.117 & 158.500 & GQ868331 \\
\hline $\begin{array}{l}\text { Pseudochrysogorgia } \\
\text { bellona n. gen., n. sp. }\end{array}$ & EBI 2557-2 & $\begin{array}{l}\text { MNHN-IC. } \\
2008-007\end{array}$ & 12.X.2005 & $800-923$ & -21.117 & 158.500 & $\begin{array}{l}\text { GQ868332, } \\
\text { GQ868310, } \\
\text { HM590865 }\end{array}$ \\
\hline $\begin{array}{l}\text { Pseudochrysogorgia } \\
\text { bellona n. gen., n. sp. }\end{array}$ & NIWA 15611 & NIWA 15611 & 9.XI.2004 & $1396-1462$ & -36.960 & 177.332 & \\
\hline $\begin{array}{l}\text { Pseudochrysogorgia } \\
\text { bellona n. gen., n. sp. }\end{array}$ & NIWA 16272 & NIWA 16272 & 10.XI.2004 & $1323-1346$ & -36.947 & 177.335 & \\
\hline $\begin{array}{l}\text { Pseudochrysogorgia } \\
\text { bellona n. gen., n. sp. }\end{array}$ & NIWA 16273 & NIWA 16273 & 10.XI.2004 & $1323-1346$ & -36.947 & 177.335 & \\
\hline $\begin{array}{l}\text { Radicipes gracilis } \\
\text { (Verrill, 1884) }\end{array}$ & 100900 & $\begin{array}{l}\text { USNM } \\
100900\end{array}$ & 5.XII.2000 & & 39.883 & -67.437 & $\begin{array}{l}\text { DQ297424, } \\
\text { HM590861, } \\
\text { HM590864 }\end{array}$ \\
\hline
\end{tabular}

May 2004 at $1485 \mathrm{~m}$ depth, and held in our lab, were used in SEM preparations (Table 1).

\section{MORPHOLOGY}

The colonies were initially found by the authors in the collections of the MNHN in 2007, photographed and sampled for genetics. Given the genetic divergence between these specimens and other chrysogorgiids at multiple loci, the specimens were re-examined in more detail in 2008. Therefore, the photographs accompanying the manuscript correspond to the colony after removal of multiple branches for genetic analyses. Measurements (e.g., colony height) were taken directly on the colony when possible, or from photographs using the program ImageJ (Abramoff et al. 2004; Rasband 1997-2008) when measuring directly was not practical (e.g., measurement of angles). All measurements of sclerites were done from light microscope imagery using ImageJ. Sclerite lengths are reported as mean \pm one standard deviation. Polyps 
TABLE 2. Morphological characteristics of the holotype and paratype of Pseudochrysogorgia bellona n. gen., n. sp. Abbreviations: $\mathbf{n}$, sample size; rg, range; $\overline{\mathbf{x}}$, mean \pm one standard deviation.

\begin{tabular}{|c|c|c|}
\hline Specimen & MNHN-IC.2008-006 (holotype) & MNHN-IC.2008-007 (paratype) \\
\hline Colony height $(\mathrm{cm})$ & 36.5 , stem broken at the base & 37 , stem broken at the base \\
\hline Colony width (cm) & $11.5-13$ & $9-13$ \\
\hline Stem diameter at the base $(\mathrm{mm})$ & 3 & 2.5 \\
\hline Stem diameter at the tip $(\mathrm{mm})$ & 1.5 & 1 \\
\hline Branch diameter at the base $(\mathrm{mm})$ & $\mathrm{n}=6, \mathrm{rg}: 1.4-1.7, \overline{\mathrm{x}}=1.65 \pm 0.20$ & $\mathrm{n}=6, \mathrm{rg}: 1.2-1.6, \overline{\mathrm{x}}=1.33 \pm 0$ \\
\hline $\begin{array}{l}\text { Branch diameter at the tip }(\mathrm{mm}) \\
\text { Branching sequence }\end{array}$ & \pm 0.13 & $\mathrm{n}=6, \mathrm{rg}: 0.3-0.5, \overline{\mathrm{x}}=\mathrm{c}$ \\
\hline Branching sequence & $2 / 7 \mathrm{R}$ & irregular, L \\
\hline Branch anasto & yes, minor & yes, impo \\
\hline $\begin{array}{l}\text { Distance between branches } \\
\text { along the stem }(\mathrm{cm})\end{array}$ & $\mathrm{n}=7, \mathrm{rg}: 1.13-1.72, \overline{\mathrm{x}}=1.39 \pm 0.19$ & $\begin{array}{c}n=12, r g: 0.99-1.7 \\
\bar{x}=1.28 \pm 0.24\end{array}$ \\
\hline Orthostiche distar & 9. & 8 \\
\hline Dista & $\mathrm{n}=15, \mathrm{rg}: 8-12, \bar{x}=9.5 \pm 1.4$ & $\mathrm{n}=18, \mathrm{rg}: 7.6-12.3, \bar{x}=9.8 \pm 1.6$ \\
\hline anches $\left({ }^{\circ}\right)$ & 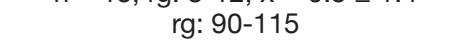 & \\
\hline Angl & rg: $100-120$ & rg: $100-130$ \\
\hline & $\mathrm{n}=7, \mathrm{rg}: 11-39, \overline{\mathrm{x}}=23.29 \pm 11.50$ & $\mathrm{n}=5, \mathrm{rg}: 10-23, \overline{\mathrm{x}}$ \\
\hline polyps / branch internode & $\begin{array}{l}0-1, \text { never on } 1 \text { st internode, } \\
\text { occasionally on } 2 \text { nd internode, } \\
\text { always on 3rd internode }\end{array}$ & $\begin{array}{l}0-1 \text {, never on } 1 \text { st internode, } \\
\text { occasionally on } 2 \text { nd internode, } \\
\text { always on 3rd internode }\end{array}$ \\
\hline Number of polyps / branch tip & & \\
\hline $\begin{array}{l}\text { Position of polyps on branch internodes } \\
\text { Presence of coenenchyme between polyps }\end{array}$ & $\begin{array}{l}\text { mostly equidistant from nodes } \\
\text { yes }\end{array}$ & $\begin{array}{c}\text { mostly equidistant from nodes } \\
\text { yes }\end{array}$ \\
\hline Polyp width (mm) & $\mathrm{n}=16, \mathrm{rg}: 1.8-3.5, \overline{\mathrm{x}}=2.7 \pm 0.50$ & $\mathrm{n}=37, \mathrm{rg}: 1.7-3.0, \overline{\mathrm{x}}=2.5 \pm 0.37$ \\
\hline & & $\mathrm{n}=30, \mathrm{rg}: 1.7-3.3$ \\
\hline $\begin{array}{l}\text { Length of sclerites from branch } \\
\text { coenenchyme }(\mu \mathrm{m})\end{array}$ & $\mathrm{n}=$ & $\mathrm{n}=2$ \\
\hline Length of sclerites from body wall $(\mu \mathrm{m})$ & $n=235, \mathrm{rg}: 37$ & $\mathrm{n}=421, \mathrm{rg}: 6$ \\
\hline & & $\mathrm{n}=$ \\
\hline
\end{tabular}

were incubated in a solution of 5\% glutaraldehyde (buffered with $\mathrm{KH}_{2} \mathrm{PO}_{4}$ and $\mathrm{Na}_{2} \mathrm{HPO}_{4}$ at $\mathrm{pH}$ 6.8) overnight to help anchor sclerites to the tissues. They were then exposed to $20 \%$ bleach for a few seconds to dissolve the epithelium covering the sclerites and make their arrangement more visible. Without exposure to glutaraldehyde, sclerites tended to fall off the polyp before the epithelium could successfully be removed. Polyps were then photographed using depth-of-field enhancement with a Keyence VHX-1000 digital microscope. Different polyps were dissected to separate tentacles, body wall and coenenchyme along branches, and tissues were then dissolved using bleach. Sclerites were rinsed multiple times in deionized water and mounted on SEM stubs using double-faced tape. Polyps were removed from branches, dehydrated in 100\% acetone, and dried using a Denton DV-2 critical-point dryer. Digital images of sclerites and polyps were generated using a Hitachi S-3000N scanning-electron microscope.
DATA ANALYSIS

\section{Phylogenetic inference}

The phylogenetic position of Pseudochrysogorgia n. gen. relative to the monophyletic, deep-sea Chrysogorgiidae (see Systematics below) was assessed using morphological and genetic data. Morphological characters distinguishing deep chrysogorgiid genera were coded as unordered, binary or multistate characters (Tables 3-4). Phylogenetic trees derived from morphological data were generated in PAUP* version 4.0b10 (Swofford 1998) using maximum parsimony. The primnoid genera Narella Gray, 1870 and Calyptrophora Gray, 1866 were chosen as outgroups (for the placement of the Primnoidae relative to the Chrysogorgiidae in a genus-level molecular phylogeny of the Octocorallia, see McFadden et al. 2006). Characters distinguishing chrysogorgiids from primnoids were defined according to Bayer (1981).

The genetic analysis was run on a 5031-bp DNA alignment composed of the nearly complete $m s h 1$ gene 
TABLE 3. - Characters and character states used in the morphology-based phylogenetic analysis of the deep Chrysogorgiidae. A dash indicates that the character was inapplicable. Abbreviations: $\mathbf{C l}$, consistency index.

\begin{tabular}{|c|c|c|}
\hline Character & States & Cl \\
\hline \multicolumn{3}{|l|}{ Morphology of the colony } \\
\hline 1. holdfast can be dendritic & 0, no; 1 , yes & 0.5 \\
\hline 2. colony branching & $\begin{array}{c}0, \text { whip; } 1 \text {, primary branching; } 2 \text {, secondary } \\
\text { branching }\end{array}$ & 0.667 \\
\hline 3. prevalent scarring along axis in adults & -, cannot score; 0 , absent; 1 , present & 1 \\
\hline 4. morphology of main stem & $\begin{array}{c}- \text {, cannot score; } 0 \text {, dichotomous; } 1 \text {, monopodial; } \\
2 \text {, sympodial }\end{array}$ & 1 \\
\hline 5. colony shape & $\begin{array}{c}- \text {, cannot score; } 1 \text {, bush / planar / flabellate; } \\
2 \text {, wide spiral; } \\
3 \text {, cluster of branches at the distal end of the axis }\end{array}$ & 0.667 \\
\hline
\end{tabular}

\section{Morphology of calyces}

6. coordination of polyps

0 , aligned and equidistant; 1 , not aligned,

1

7. orientation of calices not always equidistant; 2 , whorl

0 , up (distad); 1 , perpendicular

0.5

8. crown can be larger than neck

0 , no; 1 , yes

0.5

\section{Morphology and placement of sclerites}

9. sclerite ornamentation

10. sclerite zonation
0 , smooth; 1 , ornamented

0 , no zonation; 1 , zonation (tentacles / body / 1 coenenchyme)

\section{Characters to differentiate chrysogorgiids from outgroup}

11. polyp sclerites form suit of armor

12. crystal orientation in scales is radial

13. surface of axis longitudinally grooved

14. concentric layers of axis undulating in cross section

0, no; 1 , yes 1

0 , no; 1 , yes 1

0 , no; 1 , yes

0 , no; 1 , yes

(1)


TABLE 4. - Character matrix used in the morphology-based phylogenetic analysis, as defined by Table 3.

\begin{tabular}{lcccccccccccccc}
\hline & $\mathbf{1}$ & $\mathbf{2}$ & $\mathbf{3}$ & $\mathbf{4}$ & $\mathbf{5}$ & $\mathbf{6}$ & $\mathbf{7}$ & $\mathbf{8}$ & $\mathbf{9}$ & $\mathbf{1 0}$ & $\mathbf{1 1}$ & $\mathbf{1 2}$ & $\mathbf{1 3}$ & $\mathbf{1 4}$ \\
\hline Narella & 0 & 1 & 0 & 0 & 0 & 2 & 1 & 1 & 1 & 1 & 1 & 1 & 1 & 1 \\
Calyptrophora & 0 & 2 & 0 & 0 & 1 & 2 & 0 & 0 & 1 & 1 & 1 & 1 & 1 & 1 \\
Radicipes & 1 & 0 & - & - & - & 0 & 0 & 0 & 0 & 0 & 0 & 0 & 0 & 0 \\
Chrysogorgia & 1 & 2 & 0 & 2 & 0 & 1 & 1 & 1 & 1 & 1 & 0 & 0 & 0 & 0 \\
Iridogorgia & 0 & 1 & 0 & 1 & 1 & 0 & 1 & 0 & 0 & 0 & 0 & 0 & 0 & 0 \\
Metallogorgia & 0 & 2 & 1 & 1 & 2 & 1 & 1 & 0 & 0 & 0 & 0 & 0 & 0 & 0 \\
Pseudochrysogorgia n. gen. & 1 & 2 & 0 & 1 & 0 & 1 & 1 & 1 & 1 & 1 & 0 & 0 & 0 & 0 \\
\hline
\end{tabular}

\section{SYSTEMATICS}

\section{Classification of PSEUdochrysogorgia} N. GEN. IN THE FAMILY CHRYSOGORGIIDAE

There is strong phylogenetic support for the monophyly of the common deep-sea chrysogorgiid genera, namely Chrysogorgia, Metallogorgia, Iridogorgia Verrill, 1883, Rhodaniridogorgia Watling, 2007 and Radicipes Stearns, 1883 (based on multiple nuclear and mitochondrial markers; Pante \& France 2008: abstract). Pseudochrysogorgia n. gen. clusters with strong statistical support with the genera listed above, its closest relative being Metallogorgia (Pante \& France 2008: abstract; Fig. 8). Based on the current state of knowledge on the monophyly of genera within the family Chrysogorgiidae, a new key to the common deep-sea Chrysogorgiidae is presented. This key, modified from that of Bayer \& Stefani (1988), includes the recently-described Rhodaniridogorgia and recent observations from Mosher \& Watling (2009) on variation of branching patterns with age in Metallogorgia. It also groups Iridogorgia, Pseudochrysogorgia n. gen. and Metallogorgia based on their monopodial growth.

\section{Key to THE COMMON DEEP-SEA GENERA OF CHRYSOGORgIIDAe VERRILL, 1883}

1. Colonies unbranched, flagelliform and spirally twisted

- Colonies branched. Terminal branches originating directly from the main stem or after bifurcations of primary branches

2. Colonies sympodial, branches originate in a regular spiral around the main stem, or forming two parallel fans at the top of a short trunk. Axial skeleton has brilliant metallic luster; flexibility variable among species Chrysogorgia

- Colonies monopodial and not flabellate 3

3. Terminal branches undivided, arising from the outside of a golden, upward-spiraling main stem

- Branching in multiple planes, branches subdividing dichotomously. Axis strongly calcified, with dark, metallic luster

\section{5}

4. Main stem coiled, not wavy; presence of sclerites in the coenenchyme along branches depending on species Iridogorgia

- Main stem wavy, not coiled; array of sclerite shapes wider than in Iridogorgia, sclerites consistently present in the coenenchyme along branches Rhodaniridogorgia

5. Abundant, dichotomously-subdivided branches originate in an irregular or regular spiral around a tall, upright main stem. Distance between branches along the stem short $(<2 \mathrm{~cm})$ and regular. Polyps with ornamented sclerites of irregular shape, in the form of plates, scales and rods Pseudochrysogorgia n. gen. 
- Dichotomously-subdivided branches arising from the top of a tall, upright main stem. Juvenile colonies have additional branches arising around the main stem. In this case, distance between branches along the stem are wide ranging (up to $10 \mathrm{~cm}$ ) and irregular. Older colonies typically bear scars of past side branches along the main stem. Sclerites in the form of rods and scales, with little ornamentation Metallogorgia

Subclass OCTOCORALLIA Haeckel, 1866 Order ALCYONACEA Lamouroux, 1816 Sub-order CALCAXONIA Grasshoff, 1999 Family CHRYSOGORGIIDAE Verrill, 1883

\section{Genus Pseudochrysogorgia n. gen.}

Type SPECIES. - Pseudochrysogorgia bellona n. gen., n. sp.

EтумоLogy. - The greek prefix "pseudo", meaning "false" or "fake", is appended to Chrysogorgia in allusion to the morphological resemblance between this new taxon and the established Chrysogorgia. This resemblance is reflected by the morphology-based parsimony analysis, in which Pseudochrysogorgia n. gen. appears most closely related to Chrysogorgia rather than Metallogorgia, its sister taxon based on genetics (Fig. 8). Therefore, this combination was chosen over a combination involving Metallogorgia because misidentification of this new taxon for Chrysogorgia is more likely than misidentification for Metallogorgia. Gender is feminine.

DiAGNOSIS. - The colony is bottlebrush-shaped, and its main axis is monopodial, slightly zigzagging. Branches are subdividing dichotomously in multiple planes. Branch subdivision occurs at a relatively constant angle averaging $120^{\circ}$, resulting in hexagonal patterns. Over half of the polyps are leaning distad. The neck can be narrower than the head. On average, polyps are as wide as they are tall. Sclerites are slightly ornamented, in the form of plates, scales and rods. When the polyp is not leaning distad, sclerites are arranged obliquely on the polyp body. When polyps are leaning distad, sclerites are 1) mostly longitudinally arranged (parallel to the branch) on the polyp body, 2) placed obliquely in the area of the neck, and 3) longitudinally arranged on the head and along the back of the tentacles. The branch coenenchyme contains sclerites in the form of scales and plates that are mostly parallel to main branch axis.

\section{Pseudochrysogorgia bellona n. gen., n. sp.} (Figs 1-6; Tables 1, 2)

Holotype. - W of New Caledonia. Bellona Plateau, EBISCO stn CP 2557 (MNHN-IC.2008-006).
Paratypes. - W of New Caledonia. Bellona Plateau, EBISCO stn CP 2557 (MNHN-IC.2008-007).

N of New Zealand. Otara Seamount, stn TAN0413/41 (NIWA 16273).

ETymology. - The specific epithet refers to the type locality. Noun in apposition.

ADDiTIONAL MATERIAL EXAMINED. - Only polyps were examined (see note in Material and methods section).

N of New Zealand. Otara Seamount, stn TAN0413/35 (NIWA 15611). — stn TAN0413/41 (NIWA 16272).

DisTRIBUTION. - Known from the type locality (Bellona Plateau, Coral Sea) and Otara Seamount, at southern tip of the Kermadec Ridge ( $\mathrm{N}$ of New Zealand). The two localities are separated by approximately $2550 \mathrm{~km}$.

Diagnosis. - Same as that of the genus.

\section{DESCRIPTION}

Measurements and estimates of variation in character states are detailed in Table 2. Colonies are black and matte at the base, and are characterized by a dark metallic luster (holotype and paratype NIWA16273 black; paratype MNHN-IC.2008-007 dark brown). Branching sequence, as defined for Chrysogorgia (e.g., Versluys 1902; Cairns 2002, 2007) is 2/7R for the holotype, and irregular for the paratypes (see Discussion). The irregular branching pattern seen on the paratype is linked to the fact that the stem bifurcates and anastomoses. The distance between branches along the stem is regular, particularly on the holotype. Coenenchyme covers most of the upper part of the stem and branches and contains numerous sclerites. The stem is stiff, robust, and significantly thicker than the base of branches along most of the colony (proximal area: stem twice as thick as branches; distal area: stem and branches equally thick). Branches are stiff and stem from the main axis at nearly right angles. Order of branching is variable, mostly between four and six; the number of nodes per branch varies between 10 and 39 . Branching occurs in multiple planes. The internodal 


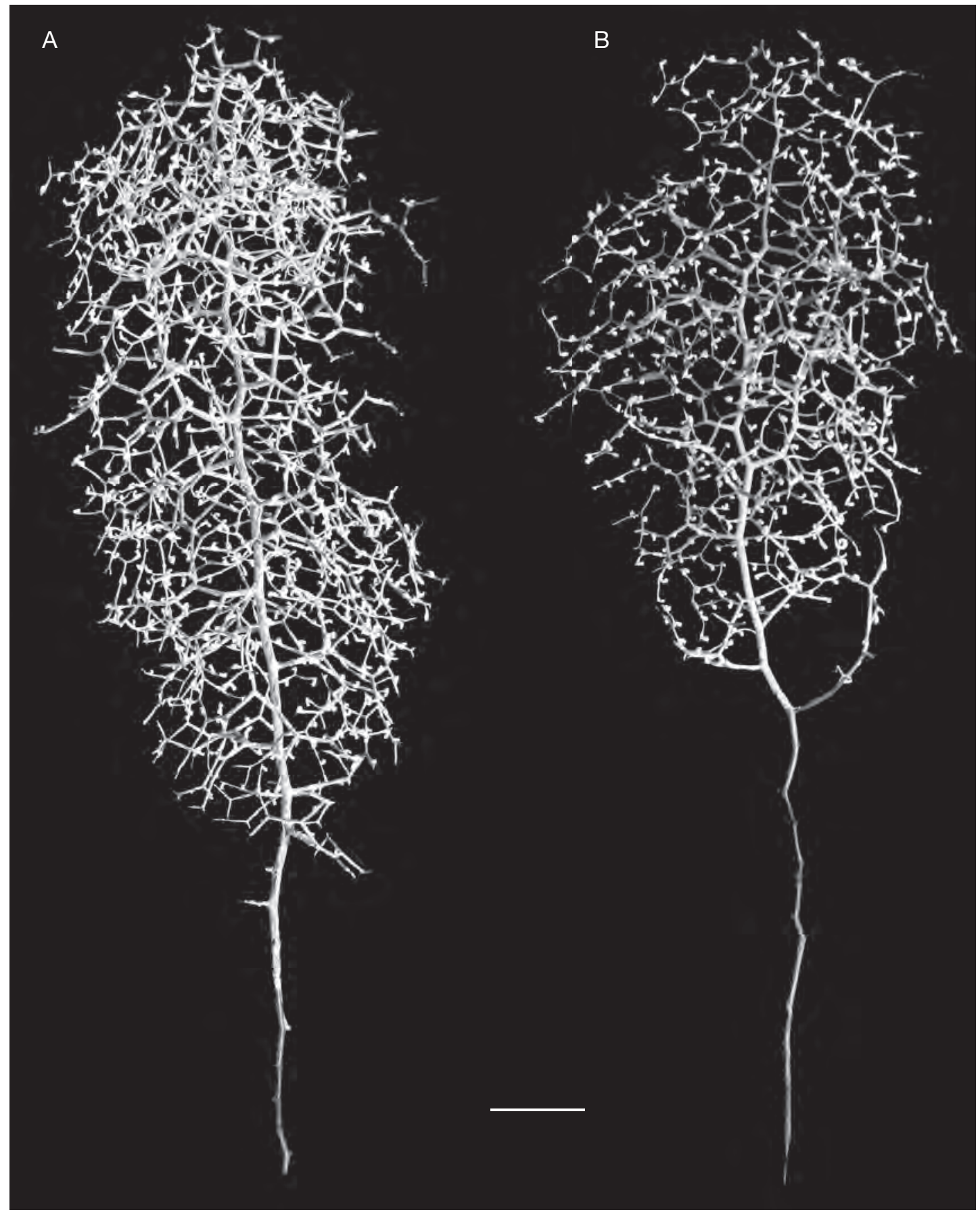

FIG. 1. - Pseudochrysogorgia bellona n.gen, n. sp.: A, holotype (MNHN-IC.2008-006); B, paratype (MNHN-IC.2008-007) from EBISCO stn CP 2557. Scale bar: $3 \mathrm{~cm}$. 
distance and the angle between subdividing branches are regular. Axial polyps were not observed on the holotype or the paratype, and polyp occurrence starts on the second branch internode. Over half of the polyps lean to one side. Polyps appear to always be leaning in the direction of branch growth. They are on average as wide as they are tall and their size varies between 1.7 and $3.5 \mathrm{~mm}$. They are constricted at the neck, a character that seems to be exacerbated when polyps are left to dry. The arrangement of sclerites is detailed in the diagnosis of the genus. Sclerites do not appear tightly interlocked: while exposing polyps to bleach in an effort to remove the upper tissue layer covering the sclerites, these would fall off the polyp very rapidly (see Material and methods). All observed types of sclerites are warted; rods are more finely warted than scales. Scales have blunt extremities. Crosses (scales and rods with four rays in one plane) are rare but occur in the coenenchyme, body wall and tentacles. Most sclerites of the coenenchyme are scales and few are plates (for example, the fourth sclerite of Figure 6A is considered as a plate). While the proximal part of the polyp body wall (anthostele) is almost exclusively covered by scales, the distal part is richer in rods. The longest rods are found at the base of the tentacles, while smaller rods are found along the back of the tentacles.

\section{REMARKS}

The holotype and the paratype MNHN-IC.2008-007 were associated with hydroids, which were attached at the tips of a few branches. While the sister taxon M. melanotrichos is found in close association with Ophiocreas oedipus Lyman, 1879 (Mosher \& Watling 2009), no brittle stars were observed on the colonies examined (however, the symbionts might have been separated during or after sampling).

Specimens from the NIWA: NIWA15611, colony highly fragmented, main stem missing; NIWA16272, colony highly fragmented, only part of the main stem is available; NIWA16273, colony fragmented, main stem present. As NIWA16272 and NIWA16273 come from the same station (TAN0413/41), and that both lots contain branch fragments, it cannot be excluded that each lot may contain fragments from more than one colony.

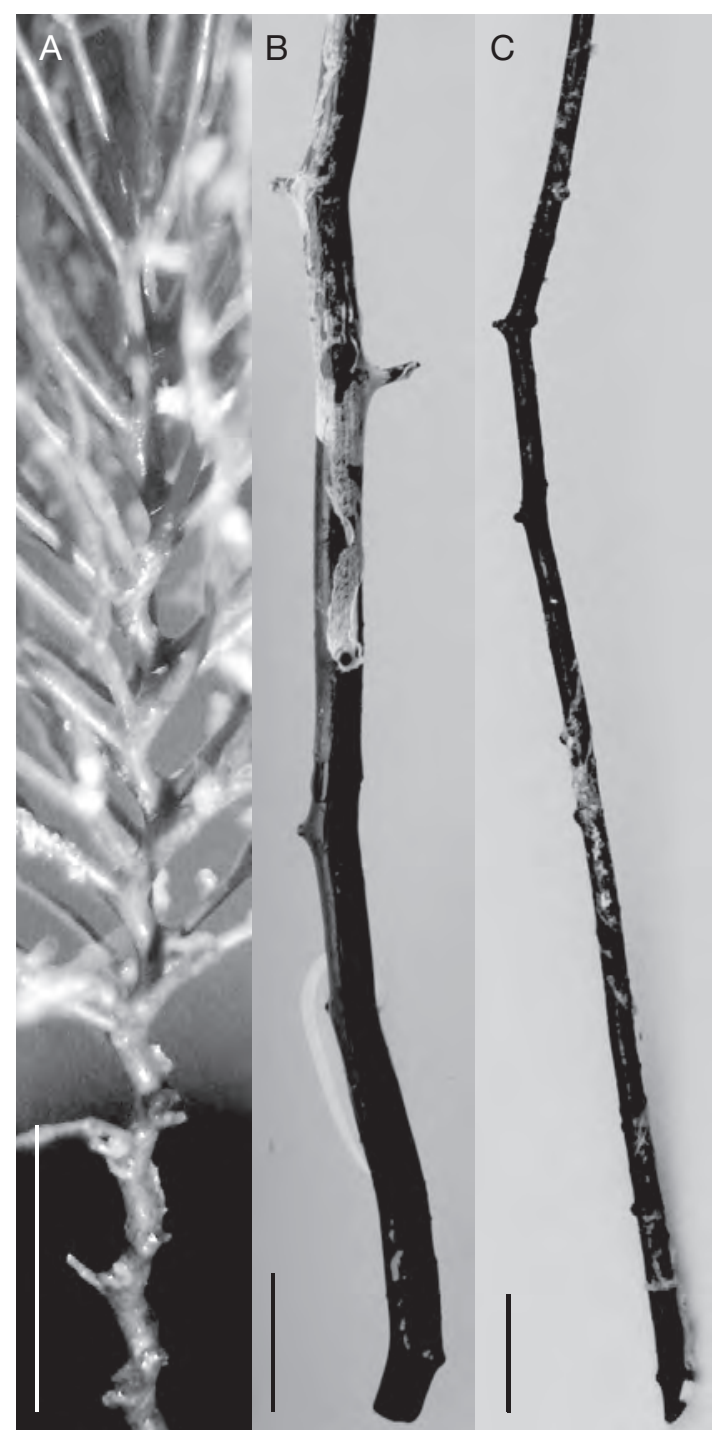

FIG. 2. - Main stems of: A, Chrysogorgia admete Bayer \& Stefani, 1988 (sympodial growth); B, Pseudochrysogorgia bellona n. gen., n. sp. (holotype); C, Metallogorgia melanotrichos (Wright \& Studer 1889) (NIWA43024; monopodial growth). Scale bars: $1 \mathrm{~cm}$.

Bifurcation pattern of secondary branches, polyp morphology, size and spacing of the NIWA specimens is consistent with that of the MNHN specimens. However, while axial polyps were not observed on the MNHN specimens, these appear to be present on NIWA16273. In addition, polyps can be observed on first internodes (Fig. 4). While the stems 

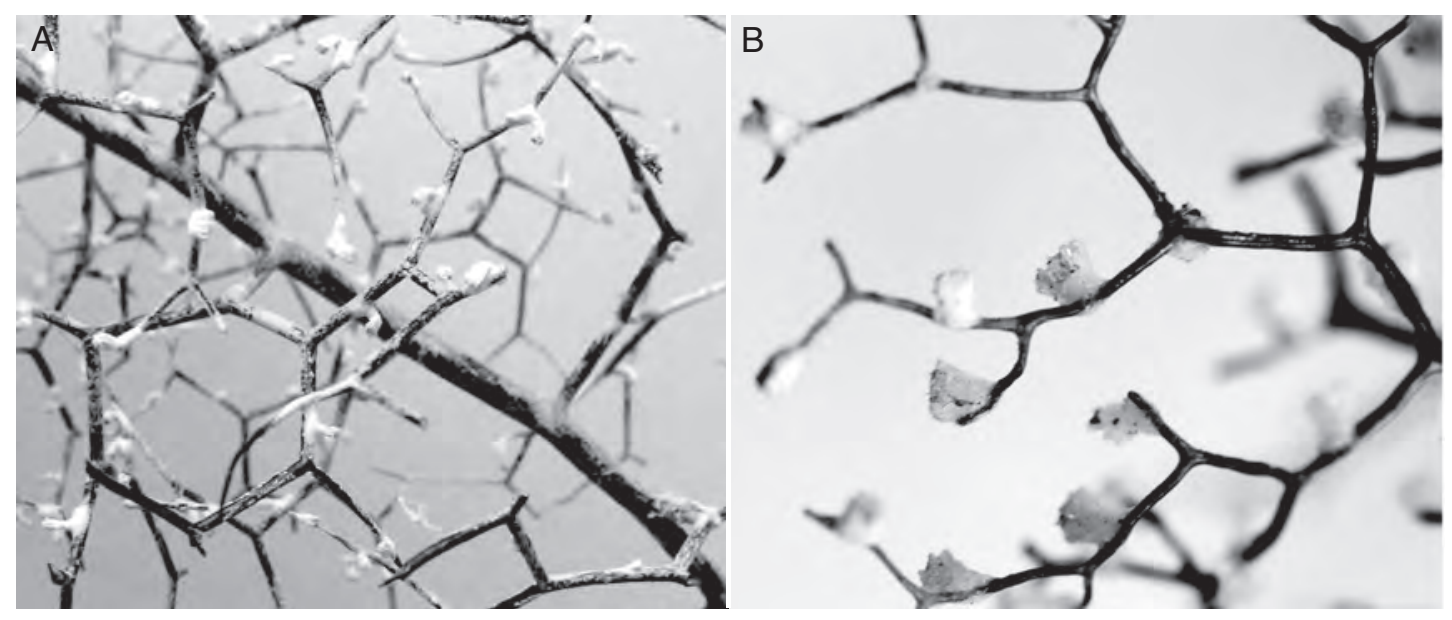

FIG. 3 - Hexagonal branching pattern in: A, the holotype of Pseudochrysogorgia bellona n. gen., n. sp.; B, Metallogorgia melanotrichos (Wright \& Studer, 1889) (NIWA43024). This branching pattern is also very clearly seen in Figure 4.

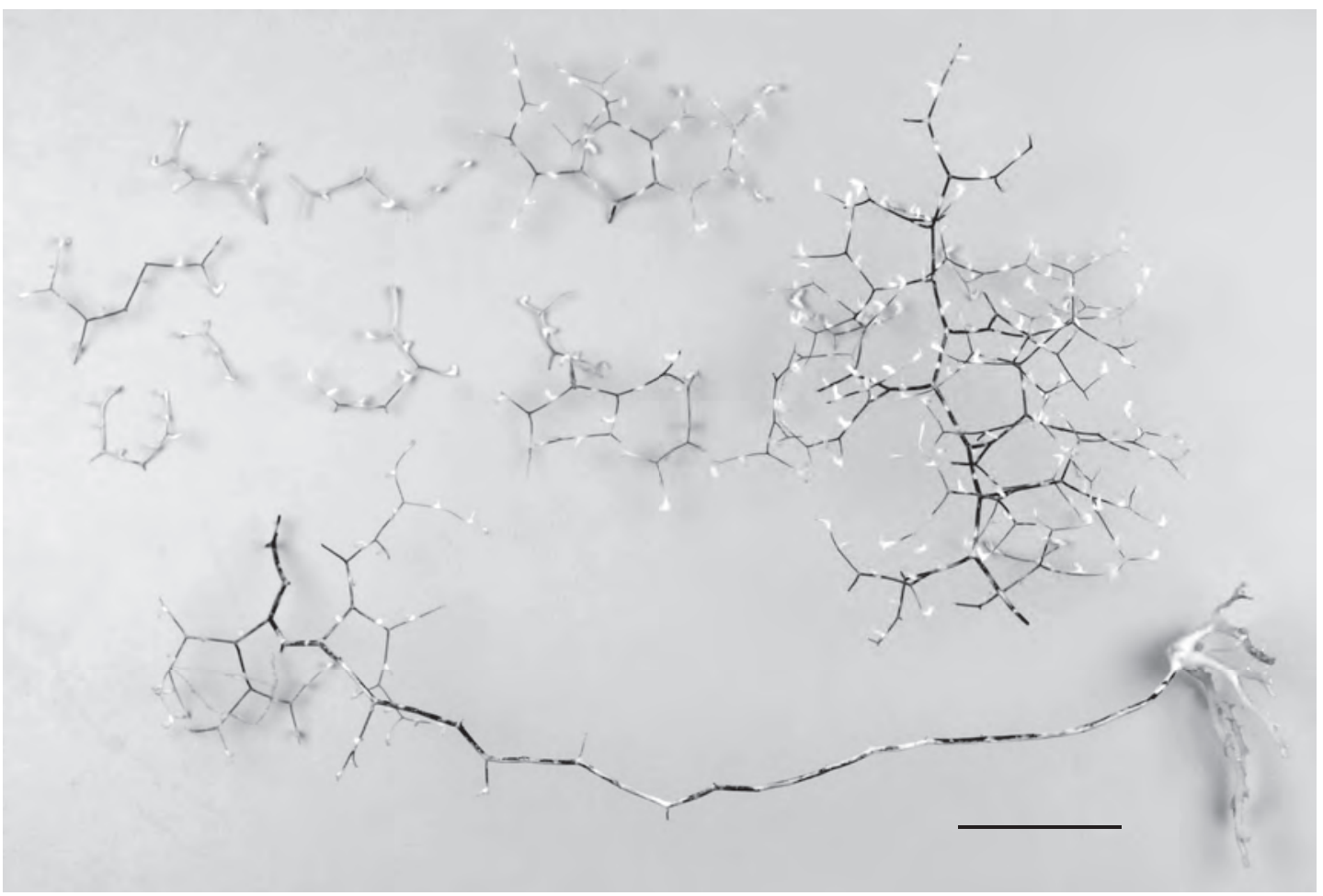

FIG. 4. - Pseudochrysogorgia bellona n. gen., n. sp. paratype (NIWA16273) from Otara Seamount, Kermadec Ridge. Scale bar: $3 \mathrm{~cm}$. 


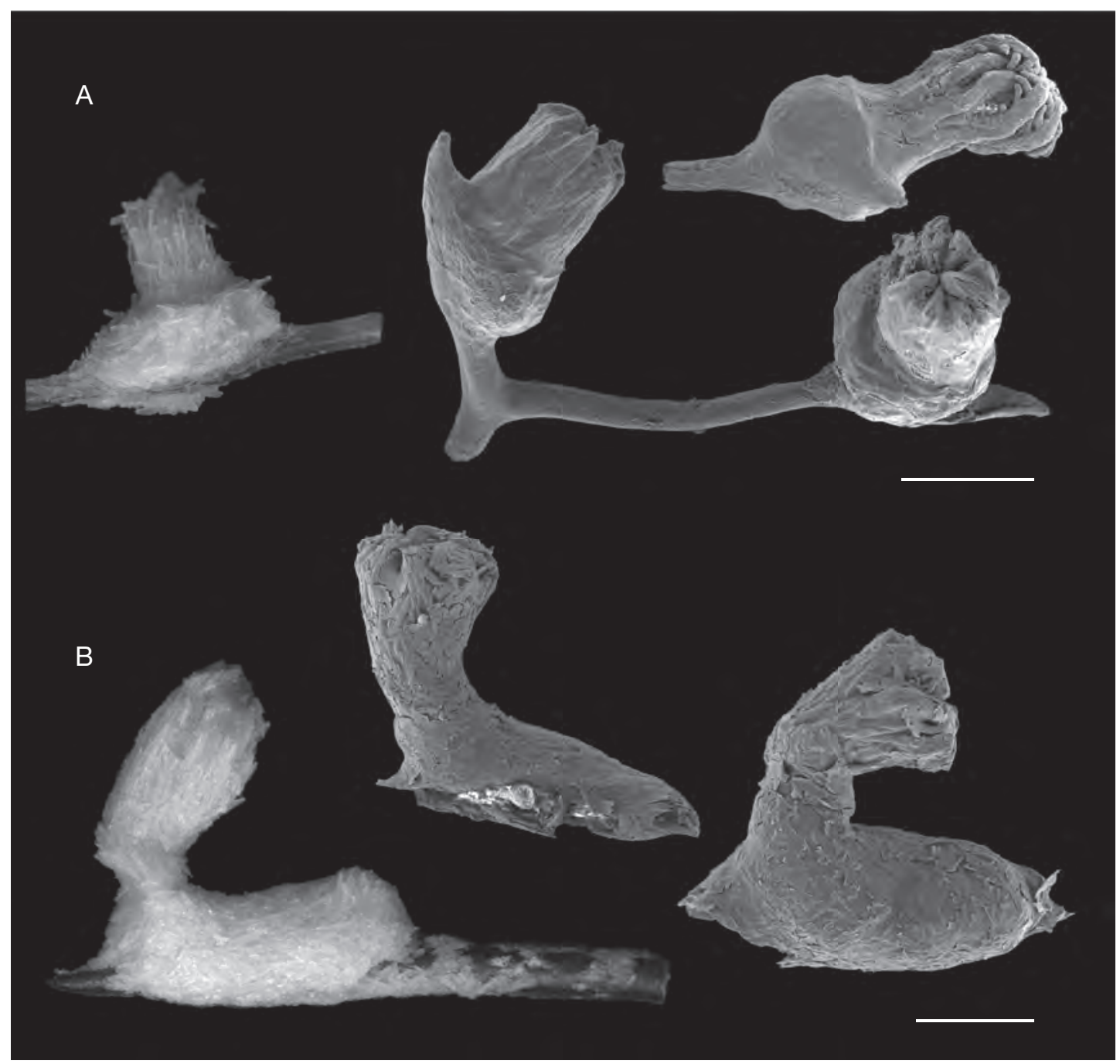

FIG. 5. - Digital (DM) and scanning-electron microscopy (SEM) images of polyps from closely-related chrysogorgiids: A, Metallogorgia melanotrichos (Wright \& Studer, 1889) (MAN806-2; left: DM, right: SEM); B, Pseudochrysogorgia bellona n. gen., n. sp. (holotype; left: DM, right: SEM). Scale bars: $1 \mathrm{~mm}$.

of both the MNHN type specimens were broken at the base, NIWA16273 had an intact, root-like holdfast (Fig. 4). This may indicate that the colony was collected from soft-sediments.

Polyp preparation: the speed at which sclerites fall from the polyp when exposed to bleach might depend on specimen fixation and preservation. Indeed, exposure to glutaraldehyde had the desired effect of locking sclerites into place, allowing for the digestion of the upper tissue layer. The same observation was made for $M$. melanotrichos. The described arrangement of sclerites (scales in body wall and rods in tentacles) corresponds to the "Squamosae aberrantes" (group B) as defined by Versluys (1902) for Chrysogorgia. Finally, polyps leaning distad have a swollen base, in which eggs can be found. This condition might be associated with the production of eggs. 


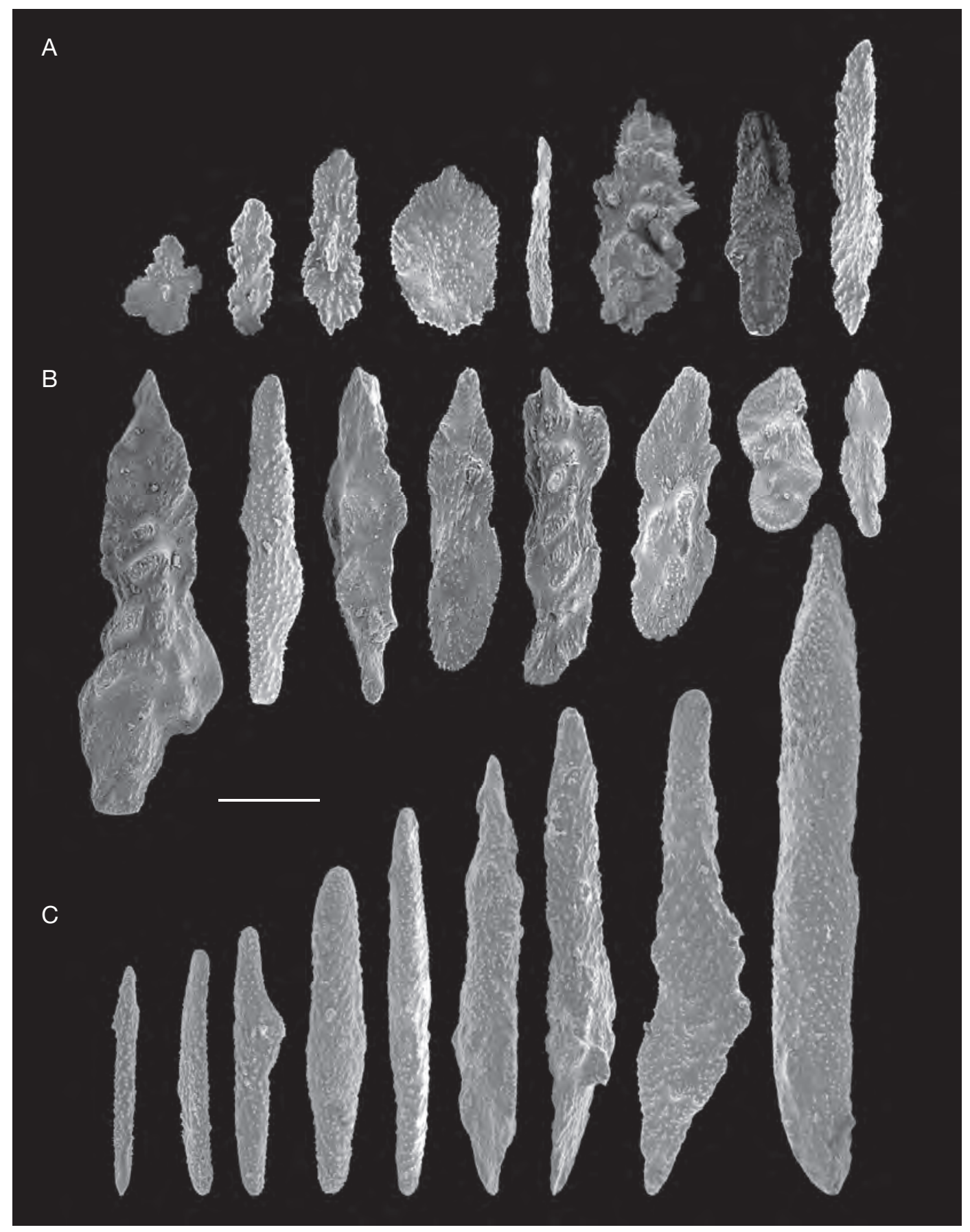

FIG. 6. - Pseudochrysogorgia bellona n. gen., n. sp. holotype, SEM of sclerites: A, branch coenenchyme; B, polyp body wall; C, tentacles. Scale bar: $100 \mu \mathrm{m}$. 


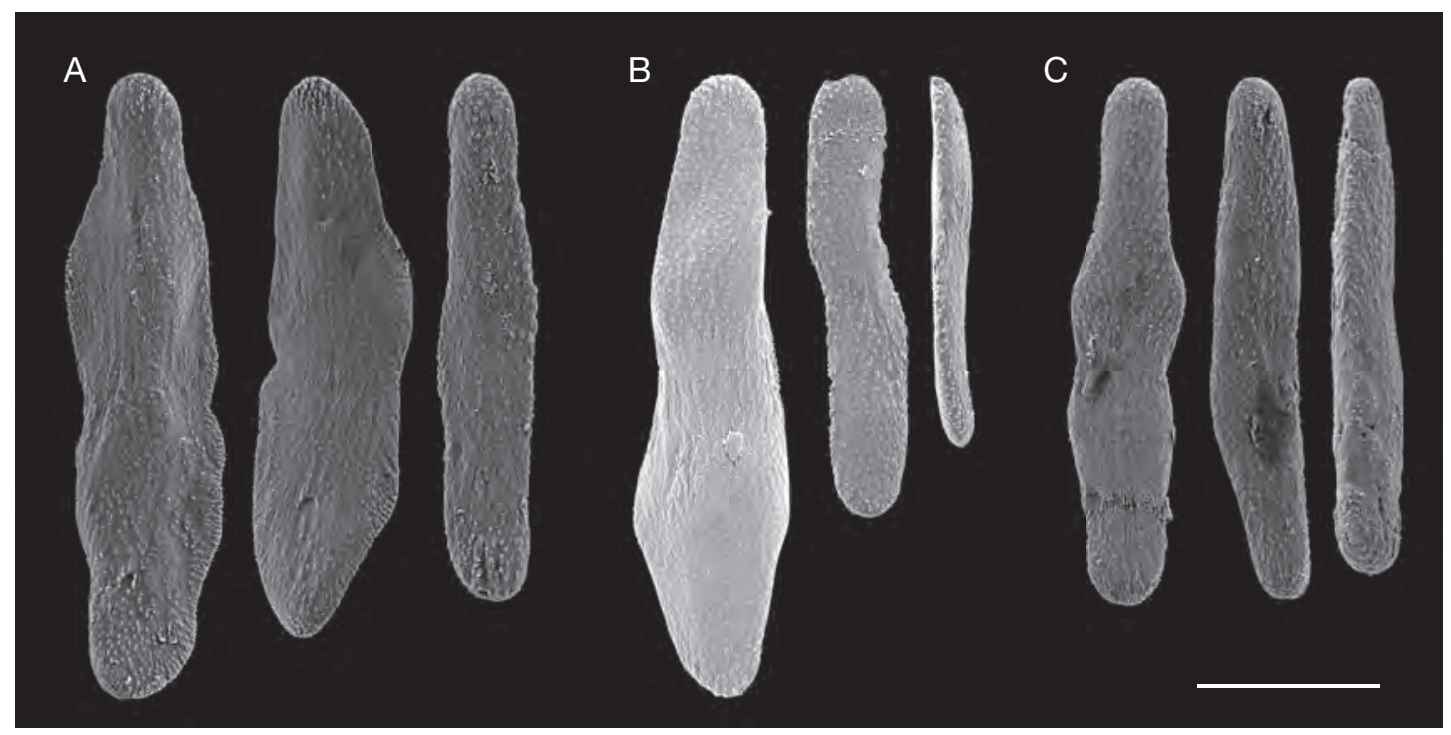

FIG. 7. - Metallogorgia melanotrichos (Wright \& Studer, 1889) (MAN806-1), SEM of sclerites: A, branch coenenchyme; B, polyp body wall; C, tentacles. Scale bar: $100 \mu \mathrm{m}$.

\section{DISCUSSION}

\section{SiMILARITY BETWEEN PSEUDOCHRYSOGORGIA}

\section{N. GEN. AND OTHER CHRYSOGORGIID GENERA}

Prior to this description, the different deep-sea chrysogorgiid genera were easily distinguished by major, strikingly different colony growth patterns, such as presence or absence of side branching, sympody or monopody of the main stem, and subdivision of side branches (see e.g., key to the genera of the Chrysogorgiidae in Bayer \& Stefani 1988). An interesting characteristic of Pseudochrysogorgia $\mathrm{n}$. gen. is the presence on the same colony of characters previously used to distinguish different genera. For instance, Pseudochrysogorgia n. gen. has abundant, bifurcating side branches along most of its stem, as does Chrysogorgia. The holotype of Pseudochrysogorgia bellona $\mathrm{n}$. gen., $\mathrm{n}$. sp. has a regular branching sequence, typical of Chrysogorgia. On the other hand, the main axis of Pseudochrysogorgia n. gen. is monopodial, as is Metallogorgia. In fact, the proximal part of the main stems of Pseudochrysogorgia n. gen. and full-grown Metallogorgia are indistinguishable, both being characterized by a dark metallic luster, heavy calcification and scars of broken branches (Fig. 2). As a consequence, Pseudochrysogorgia $\mathrm{n}$. gen. could easily be misidentified (and indeed, the Pseudochrysogorgia n. gen. specimens from the NIWA were originally labelled as Chrysogorgia). While both Pseudochrysogorgia $\mathrm{n}$. gen. and juvenile $M$. melanotrichos branch patterns can easily be differentiated (photographs of branching M. melanotrichos can be found in Mosher \& Watling 2009). The main difference resides in the spacing of branches along the stem, which is regular and narrow in Pseudochrysogorgia n. gen. and irregular and sparse in $M$. melanotrichos.

In addition to closely examining the main stem, sclerite morphology can provide information on the specimen examined. Indeed, while Metallogorgia sclerites are typically rod-shaped (scales are much less abundant, typically thick and rounded) and lightly ornamented, Pseudochrysogorgia n. gen. sclerites have more diverse shapes (plates, scales and rods), and are significantly more ornamented. The proximal portions of Pseudochrysogorgia n. gen. polyps are almost exclusively composed of scales. The length of sclerites should be compared with caution. While on average $M$. melanotrichos has smaller sclerites than P. bellona n. gen., n. sp. (MAN806-1: 
DNA-based phylogeny

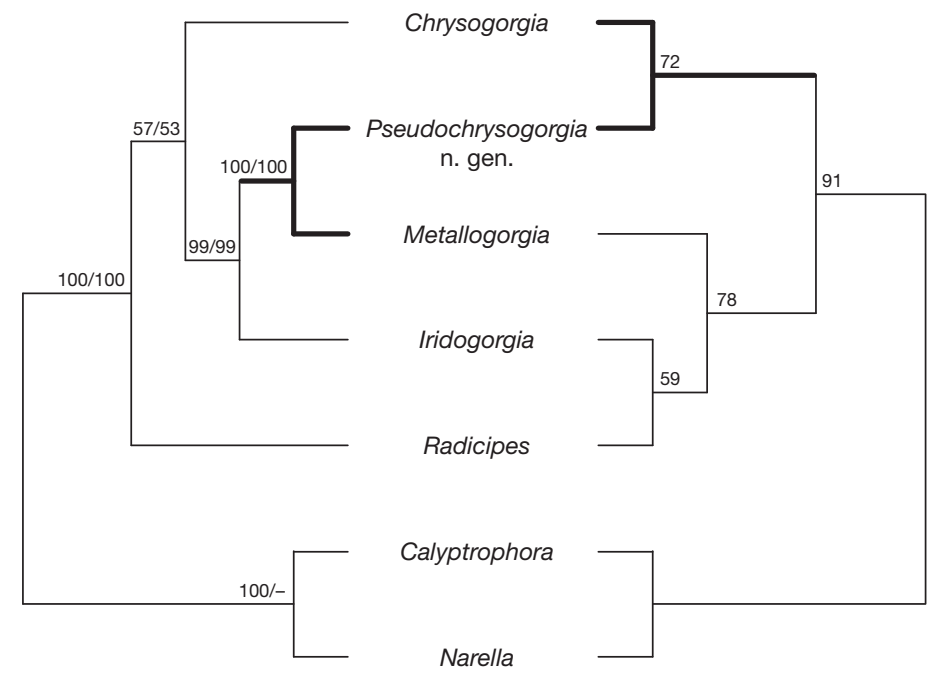

FIG. 8. - Phylogenetic trees based on genetic (left) and morphological (right) data. The morphology-based cladogram has a length of 23 steps, a consistency index of 0.7826 and a retention index of 0.7222 . The DNA-based cladogram is presented with bootstrap values from maximum likelihood and maximum parsimony analyses (left and right of slash, respectively). Bold lines emphasize the relationship between Pseudochrysogorgia n. gen. and its closest relative, and the inconsistency between morphology-and DNA-based inference of the phylogeny.

mean $179 \pm 56 \mathrm{~mm}$, range $46-304 \mathrm{~mm}, \mathrm{n}=129)$, $M$. macrospina is characterized by longer sclerites (MNHN-IK-2008-1042: mean 408 $197 \mathrm{~mm}$, range $134-1036 \mathrm{~mm}, \mathrm{n}=106)$. Pseudochrysogorgia n. gen. polyps tend to be more rotund than those of Metallogorgia and more than half are slightly angled to the branch (see description and Figure 5). To our knowledge, there are no published SEM photographs of Metallogorgia polyps or sclerites. For comparison, we present herein SEM pictures of typical $M$. melanotrichos polyps and sclerites (Figs 5; 7).

\section{TAXONOMIC RANK OF PSEUDOCHRYSOGORGIA}

\section{N. GEN.}

There is no single morphological character state that could serve as a synapomorphy to distinguish P. bellona n. gen., n. sp. from the rest of the deep-sea Chrysogorgiidae. One can legitimately ask why this taxon should not simply be considered a new species of Metallogorgia. To answer this question we looked at the molecular variation between species from different genera within the family. The genetic distance between $P$. bellona n. gen., n. sp. and M. melanotrichos (1.897\%) falls into an area of overlap between intra- and inter-generic comparisons (Fig. 9). Comparatively, distances between P. bellona n. gen., n. sp. and Chrysogorgia range between 2.9 and $4.5 \%$. The distributions of intra- and intergeneric comparisons are both bimodal. In the first case, all distances larger than $1.454 \%$ are between Chrysogorgia specimens. In the second case, all distances smaller than 3.245\% are exclusively between Radicipes and Chrysogorgia specimens (gray areas of Fig. 9). Pairs of Chrysogorgia species can therefore be more divergent than Chrysogorgia-Radicipes pairs. If genetic distance is used as a diagnostic tool for attributing taxonomic levels to Chrysogorgiidae species, then one of two possible changes should be made to prevent distributions of intra- and inter-generic distances from overlapping:

1. Radicipes and Chrysogorgia should be grouped as one genus. In this case, the gray area in the lower panel of Fig. 9 ceases to be, and P. bellona n. gen., n. sp. can be considered as a new species of Metallogorgia. 
2. Radicipes and Chrysogorgia should be considered as two different genera, and Chrysogorgia should be further divided into different groups. In this case, the gray area in the upper panel of Figure 9 ceases to be, and P. bellona n. gen., n. sp. cannot be considered as a new species of Metallogorgia.

The strong morphological differences between Radicipes and Chrysogorgia restrain us from suggesting that these two genera should be grouped as one genus. In addition, molecular phylogenetics suggest that these groups form two reciprocally monophyletic groups (Pante \& France unpublished). Finally, Chrysogorgia is known to be a very diverse taxon, and authors have previously suggested the division of this genus into three groups (the "Spiculosae", the "Squamosae typicae", and the "Squamosae aberrantes"), based on the zonation of different sclerite types (Wright \& Studer 1889; Versluys 1902).

While P. bellona n. gen., n. sp. is more closely related to Chrysogorgia based on morphology, its closest relative based on genetics is Metallogorgia (Fig. 8). This conflicting result underlines the special status of $P$. bellona n. gen., n. sp. in the family, and suggests that incorporating this new taxon within the genus Metallogorgia would make a new, broadened definition of Metallogorgia problematic, as it would significantly overlap with the definition of Chrysogorgia. If Metallogorgia is redefined, monopody would be the only strong synapomorphy differentiating it from Chrysogorgia. This character, however, is difficult to assess in some cases (unpublished observations from EP).

Finally, the genetic distance between $P$. bellona n. gen., n. sp. and $M$. melanotrichos, while small compared to other inter-generic distances, is quite large when considering the currently observed variation among Metallogorgia specimens. DNA from 57 specimens from the Atlantic and Pacific oceans were sequenced at $m s h 1$, and only two genetic variants were found (Thoma et al. 2009; Pante \& France unpublished), represented by $M$. melanotrichos and M. macrospina. Metallogorgia macrospina is rare and is represented by only two specimens. These two Metallogorgia haplotypes are only $0.144 \%$ divergent, and colonies can only be clearly differentiated by the size of rods on the polyp head. Similarly, the
Intra-generic comparisons

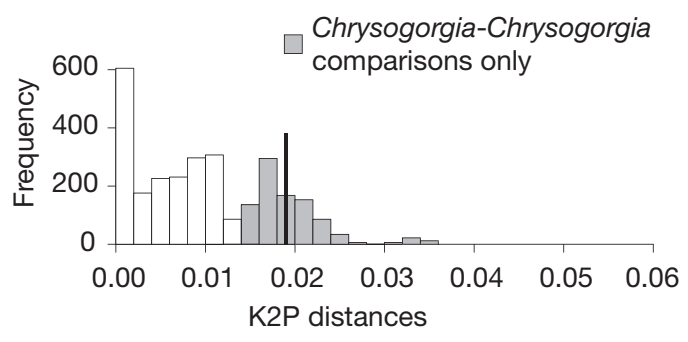

Inter-generic comparisons

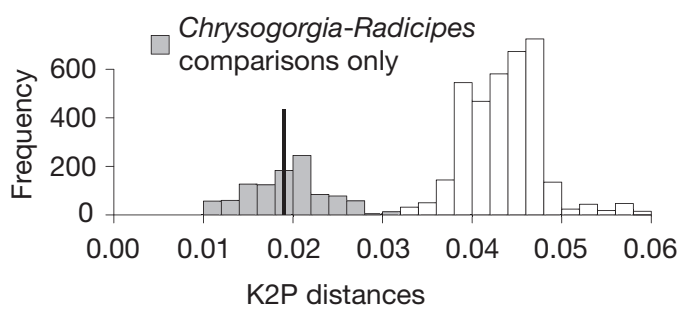

FIG. 9. - Frequency histograms of pairwise genetic distance values (K2P) across 129 chrysogorgiid specimens sequenced at the 5' end of msh1. Separate histograms are shown for pairwise comparisons made among congeneric individuals (top) and between individuals from different genera (bottom). The vertical black line represents the K2P distance between Pseudochrysogorgia bellona n. gen., n. sp. and its closest relative, Metallogorgia melanotrichos (Wright \& Studer, 1889).

maximum genetic distance between currently known Iridogorgia haplotypes $(\mathrm{n}=4)$ is only $0.576 \%$, compared to the $1.897 \%$ separating P. bellona n. gen., n. sp. from the most common Metallogorgia haplotype. The monophyletic clade comprising Metallogorgia, Iridogorgia and Pseudochrysogorgia n. gen. might evolve at a slower pace than Chrysogorgia. Also, species within this clade might have recently diverged (these two hypotheses are not mutually exclusive). Because Pseudochrysogorgia n. gen. is nested between Iridogorgia and Metallogorgia within this clade, we argue that the genetic distance separating Metallogorgia from Pseudochrysogorgia n. gen. should be interpreted in light of the small genetic distances found within the clade. In conclusion, based on these lines of evidence (problematic revision of Metallogorgia, incongruence between morphology-based and DNA-based phylogenies, and analyses of genetic distances), we suggest that 
P. bellona n. gen., n. sp. deserves recognition as the type of a new genus, rather than a new species of Metallogorgia.

\section{VARIATION IN BRANCHING SEQUENCE}

The type specimens of $P$. bellona n. gen., n. sp. differ significantly in branching sequence. First, side branches of the holotype arise in a dextral (R) spiral, while the MNHN paratype is characterized by a sinistral (L) spiral. In addition, branching was fairly regular for the holotype, following a 2/7R sequence (two side branches are in the same plane if they are separated by six side branches and two revolutions; in other terms, "traveling" along the main stem, it takes seven branches and two revolutions to recover the plane of a starting, reference side branch). It is noteworthy that this particular sequence has never been reported for Chrysogorgia (Cairns 2001, 2002, 2007). On the MNHN paratype, side branches arise irregularly around the main stem. The spiral can be interrupted by perfectly aligned, consecutive side branches, and dichotomous subdivision (and subsequent anastomosis) of the main stem. While we could not directly assess branching sequence for the NIWA paratype, branching appears to be irregular, as for the MNHN paratype (Peter Marriott and Sadie Mills, NIWA, pers. comm.).

Despite these differences in branching sequence, the holotype and MNHN paratype of $P$. bellona n. gen., n. sp. are very similar for other traits, such as spacing of side branches along the main stem, dichotomous sub-branching, and dimensions (summarized in Table 2). In addition, the three type specimens were genetically identical along a region of the mitochondrial genome spanning 3155 base pairs, crossing part of the nad $4 l$ and the entire msh1 (Pante and France, unpublished). The msh 1 gene is the most variable marker available for octocorals to date, and allows discrimination of many species (McFadden et al.2006, 2010, and references therein). Morphological variation contrasted by lack of molecular variation could either indicate that branching sequence is not a taxonomically useful character within the genus Pseudochrysogorgia n. gen. and might depend on environmental factors, or that multiple, recentlydiverged species exist within the genus, and the genetic marker used here is not sufficiently variable to differentiate them.

Of these two alternatives, the dependence of branching sequence on environmental variables might be the most likely. First, variable branching sequence within colonies does occur within the genus Chrysogorgia. Of the 59 valid species listed by Cairns (2001), six have an irregular sequence, and three have multiple but regular sequences. For example, $C$. herdendorfi Cairns, 2001 is characterized by a dominant $2 / 5 \mathrm{R}$ sequence, sometimes interrupted by a 3/8R sequence. Similarly, the spiral of C. squamata (Verrill, 1883) can follow a 1/5R (predominantly), 1/6R, or even a $1 / 7 \mathrm{R}$ sequence (Cairns 2001). At the scale of individual colonies, significant variation in spiral characteristics suggests environmental control of growth pattern. One hypothesis is that colonies are subjected to increased drag as they grow taller, and increased tension on the main stem disturbs the regularity of the spiral. Second, lack of congruence between variation in branching pattern and genetic data has previously been documented. For instance, lack of colony branching has long been used to distinguish Lepidisis Verrill, 1883 from Keratoisis Wright, 1869 (Isididae Lamouroux, 1812), but analyzing part of the msh 1 gene does not recover the two genera as discrete, monophyletic clades (France 2007).

Although branching sequence can be used to differentiate some species of Chrysogorgia (see e.g., Cairns 2001), we chose to pool both Pseudochrysogorgia n. gen. type specimens within the same species, based on the observations described above. Should more material become available, morphological and genetic variation within this new genus will be further tested.

\section{Acknowledgements}

The authors wish to thank Aude Andouche and Philippe Maestrati for their help with the MNHN collections. Specimens from New Zealand were provided by the NIWA Invertebrate Collection, and were collected during the Voyage TAN0413; "Seamounts: their importance to fisheries and marine ecosystems", undertaken by the NIWA and funded by the New Zealand Foundation for Research, Science 
and Technology with additional funding from the Ministry of Fisheries. Sadie Mills, Kareen Schnabel and Peter Marriott (NIWA) provided videos and photographs of these specimens. Les Watling provided insights on sclerite and polyp preparation for SEM. Jana Thoma (France Lab, UL Lafayette), Michael Purpera and Tom Pesacreta (Microscopy Center, UL Lafayette) helped with specimen preparation and microscopy. Photographs taken on the Keyence VHX-1000 were taken during a demonstration by Keyence sales executive Bradley Caillouet. His help is much appreciated. Amélia Viricel helped in the laboratory. Les Watling, Phil Alderslade, Stephen Cairns and Annemarie Ohler provided significant insight on the study. Financial support was provided by Sigma Xi (Grants-in-Aid of Research Program, award \#GIARG20061021830514629), the American Museum of Natural History (Lerner Gray Fund), the UL Lafayette Graduate Student Organization, and a subcontract to SCF from a National Science Foundation grant, Assembling the Cnidarian Tree of Life (\#EF-0531570).

\section{REFERENCES}

Abramoff M., Magelhaes P. \& Ram S. 2004. — Image processing with ImageJ. Biophotonics International 11 (7): 36-42.

AVISE J. 2004. - Molecular Markers, Natural History, and Evolution. Second edition. Sinauer Associates, Sunderland, Massachusetts, $684 \mathrm{p}$.

BAYER F. M. 1981. - Key to the genera of Octocorallia exclusive of the Pennatulacea (Coelenterata: Anthozoa), with diagnoses of new taxa. Proceedings of the Biological Society of Washington 94 (3): 902-947.

Bayer F. \& Stefani J. 1988. - A new species of Chrysogorgia (Octocorallia: Gorgonacea) from New Caledonia, with descriptions of some other species from the Western Pacific. Proceedings of the Biological Society of Washington 101 (2): 257-279.

CAIRns S. D. 2001. - Studies on western Atlantic Octocorallia (Coelenterata : Anthozoa). Part 1: The genus Chrysogorgia Duchassaing \& Michelotti, 1864. Proceedings of the Biological Society of Washington 114 (3): 746-787.

CAIRnS S. D. 2002. - A new species of Chrysogorgia (Anthozoa : Octocorallia) from the Antarctic. Proceedings of the Biological Society of Washington 115 (1): 217-222.

CAIRns S. D. 2007. — Calcaxonian octocorals (Cnidaria;
Anthozoa) from Eastern Pacific Seamounts. Proceedings of the California Academy of Sciences 58 (25): 511-541.

FranCE S. 2007. - Genetic analysis of bamboo corals (Cnidaria: Octocorallia: Isididae): does lack of colony branching distinguish Lepidisis from Keratoisis? Bulletin of Marine Science 81 (3): 323-333.

GUINDON S. \& GASCUEL O. 2003. - A simple, fast, and accurate algorithm to estimate large phylogenies by maximum likelihood. Systematic Biology 52 (5): 696-704. DOI: 10.1080/10635150390235520.

Kimura M. 1980. — A simple method for estimating evolutionary rates of base substitutions through comparative studies of nucleotide-sequences. Journal of Molecular Evolution 16 (2): 111-120.

McFadden C. S., Benayahu Y., Pante E., Thoma J. N., Nevarez P. A. \& FranCE S. C. 2010. - Limitations of mitochondrial gene barcoding in Octocorallia. Molecular Ecology Resources DOI: 10.1111/j.17550998.2010.02875.x.

McFadden C. S., France S. C., Sanchez J. A. \& Alderslade P. 2006. - A molecular phylogenetic analysis of the Octocorallia (Cnidaria : Anthozoa) based on mitochondrial protein-coding sequences. Molecular Phylogenetics and Evolution 41 (3): 513-527.

Mosher C. \& WatLing L. 2009. - Partners for life: a brittle star and its octocoral host. Marine Ecology-Progress Series 397: 81-88. DOI: 10.3354/meps08113.

Pante E. \& France S. C. 2008. - The first molecular phylogenetic reconstruction of the Chrysogorgiidae (Anthozoa: Octocorallia) questions its monophyly. In 4th International Symposium on Deepsea Corals. Wellington New Zealand: 151.

Paradis E., Claude J. \& Strimmer K. 2004. - APE: analyses of phylogenetics and evolution in $\mathrm{R}$ language. Bioinformatics 20: 289-290.

PosadA D. 2008. — jModelTest: Phylogenetic model averaging. Molecular Biology and Evolution 25 (7): 1253-1256.

R DeVElopment Core Team. 2010. - R: A Language and Environment for Statistical Computing. R Foundation for Statistical Computing, Vienna, Austria. URL http:// www.R-project.org. ISBN 3-900051-07-0.

RASBAND W. 1997-2008. — ImageJ. Technical report, U. S. National Institutes of Health, Bethesda, Maryland, USA. URL http://rsb.info.nih.gov/ij/.

SwOFFORD D. L. 1998. - PAUP*. Phylogenetic Analysis Using Parsimony ( ${ }^{*}$ and other methods). Version 4.0610 for Macintosh (PPC). Sinauer Associates, Sunderland, Massachusetts.

Tamura K., Dudley J., Nei M. \& Kumar S. 2007. MEGA4: Molecular evolutionary genetics analysis (MEGA) software version 4.0. Molecular Biology and Evolution 24 (8): 1596-9.

Thoma J., Pante E., Brugler M. \& France S. 2009. Deep-sea octocorals and antipatharians show no 
evidence of seamount-scale endemism in the NW Atlantic. Marine Ecology - Progress Series 397: 25-35. DOI: $10.3354 /$ meps08318.

VersLuYs J. 1902. - Die Gorgoniden der Siboga-Expedition. I. Die Chrysogorgiiden, volume 13. Monographie Siboga-Expeditie, $120 \mathrm{p}$.

WATLING L. 2007. - A review of the genus Iridogorgia (Octocorallia: Chrysogorgiidae) and its relatives, chiefly from the North Atlantic Ocean. Journal of the Marine Biological Association of the United Kingdom 87 (2): 393-402.

WRIGHT E. \& STUDER T. 1889. - Report on the Alcyonaria collected by the H.M.S. Challenger during the years 1873-76-Report on the scientific results of the voyage of H.M.S. Challenger during the years 1872-76, volume Zoology 31: 1-314, pls 1-43.

Submitted on 21 September 2009; accepted on 15 June 2010. 